\title{
Central Asia Environmental Security Technical Workshop: Responding to the CENTCOM Vision
}

\author{
R.B. Knapp
}

August 1, 2002

U.S. Department of Energy

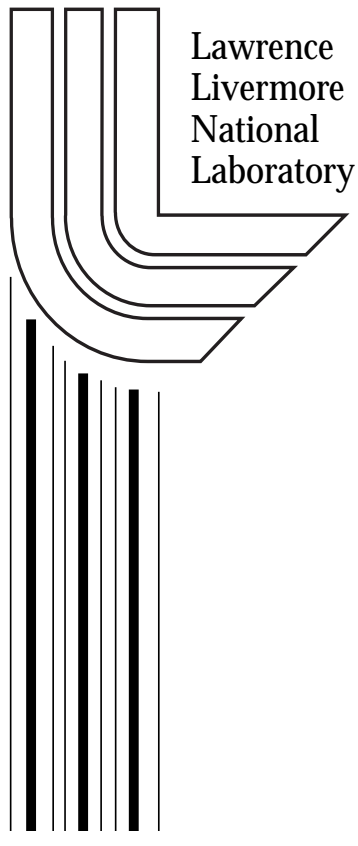




\section{DISCLAIMER}

This document was prepared as an account of work sponsored by an agency of the United States Government. Neither the United States Government nor the University of California nor any of their employees, makes any warranty, express or implied, or assumes any legal liability or responsibility for the accuracy, completeness, or usefulness of any information, apparatus, product, or process disclosed, or represents that its use would not infringe privately owned rights. Reference herein to any specific commercial product, process, or service by trade name, trademark, manufacturer, or otherwise, does not necessarily constitute or imply its endorsement, recommendation, or favoring by the United States Government or the University of California. The views and opinions of authors expressed herein do not necessarily state or reflect those of the United States Government or the University of California, and shall not be used for advertising or product endorsement purposes.

This work was performed under the auspices of the U. S. Department of Energy by the University of California, Lawrence Livermore National Laboratory under Contract No. W-7405-Eng-48.

This report has been reproduced directly from the best available copy.

Available electronically at http://www.doc.gov/bridge

Available for a processing fee to U.S. Department of Energy

And its contractors in paper from

U.S. Department of Energy

Office of Scientific and Technical Information

P.O. Box 62

Oak Ridge, TN 37831-0062

Telephone: (865) 576-8401

Facsimile: (865) 576-5728

E-mail: reports@adonis.osti.gov

Available for the sale to the public from

U.S. Department of Commerce

National Technical Information Service

5285 Port Royal Road

Springfield, VA 22161

Telephone: (800) 553-6847

Facsimile: (703) 605-6900

E-mail: orders@ntis.fedworld.gov

Online ordering: http://www.ntis.gov/ordering.htm

OR

Lawrence Livermore National Laboratory

Technical Information Department's Digital Library

http://www.llnl.gov/tid/Library.html 


\section{Central Asia Environmental Security Technical Workshop: Responding to the CENTCOM Vision}

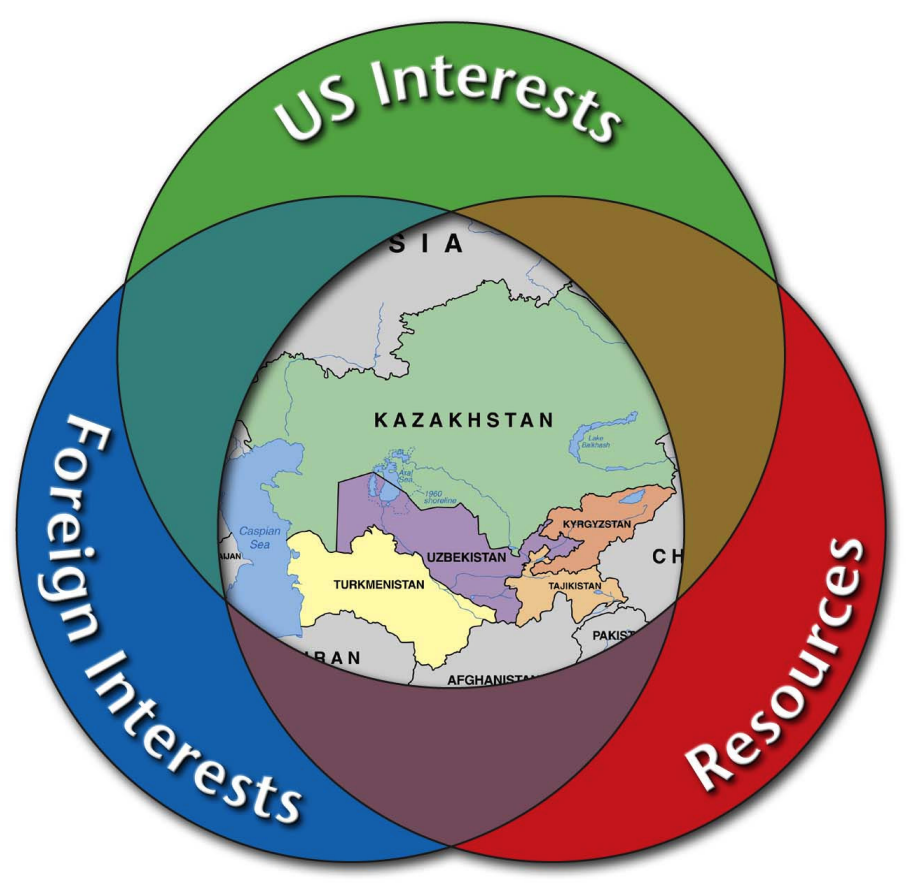

UCRL ID-149838

Lawrence Livermore National Laboratory

Livermore California

Tuesday and Wednesday

6 and 7 August 2002 


\section{Disclaimer}

This document was prepared as an account of work sponsored by an agency of the United States Government. Neither the United States Government nor the University of California nor any of their employees, makes any warranty, express or implied, or assumes any legal liability or responsibility for the accuracy, completeness, or usefulness of any information, apparatus, product, or process disclosed, or represents that its use would not infringe privately owned rights. Reference herein to any specific commercial product, process, or service by trade name, trademark, manufacturer, or otherwise, does not necessarily constitute or imply its endorsement, recommendation, or favoring by the United States Government or the University of California. The views and opinions of authors expressed herein do not necessarily state or reflect those of the United States Government or the University of California, and shall not be used for advertising or product endorsement purposes.

This work was performed under the auspices of the U.S. Department of Energy by the University of California, Lawrence Livermore National Laboratory under Contract No. W-7405Eng-48. 


\section{Table of Contents}

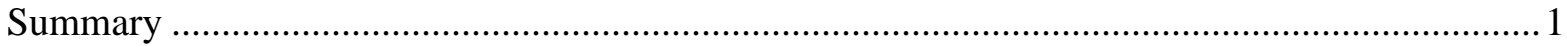

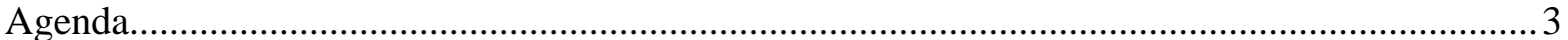

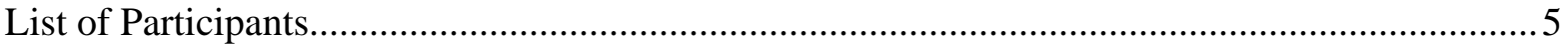

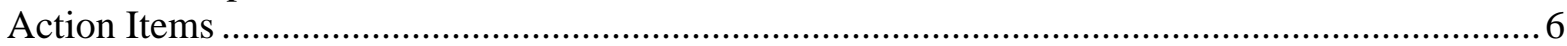

USCENTCOM Environmental Security Program …...................................................

The LLNL STARS Program ................................................................................................. 14

The Central Region Environmental Security Program....................................................... 21 


\section{Summary}

Environmental security is not formally classified as a "vital mission" in the USCENTCOM ranking of priorities in its area of responsibility. Rather, it is ranked as an "other/important" mission in Central Asia, thereby supporting the war making efforts in the region by improving stability of the regimes in the region. Environmental security is, however, the USCENTCOM primary mechanism for engagement in the region. USCENTCOM sees environmental issues as among the most destabilizing issues in the region; anything that can be done to ameliorate them, works to enhance stability. By environmental issues, USCENTCOM includes:

- water access, quality, and control,

- transboundary resource competition,

- migration of pollutants,

- land use,

- public health/HIV/Famine, and

- industrial pollution.

Objectives of USCENTCOM work in Central Asia are:

- improving resource use,

- disaster response,

- international cooperation, and

- civil-military cooperation, particularly with the local military and between the local civilians and the U.S. military.

Activities to date include assistance, education, and military-to-military contacts, bilateral and multilateral conferences on the issues, and interagency coordination in the region. The Comprehensive Threat Reduction program has been the backbone of its Central Asian funding.

LLNL briefed its Science and Technology to Advance Regional Security (STARS) program in Central Asia. STARS is not an assistance program. Instead, STARS collaboratively addresses problems that lie at the intersection of U.S. interests, foreign interests, and expected resources. STARS projects must include a partner from at least one Central Asian state and must address a problem related to:

- disaster response,

- environmental quality,

- natural hazards,

- border security, and/or

- water resources.

LLNL experience with science and technology investments in the former Soviet Union suggests and enormous return on investment, in terms of both local effort and local currencies. 
In response to a USCENTCOM request, the Central Asian Regional Environmental Officer (REO) developed two cables (Tashkent 1818 and Tashkent 2452) outlining regional environmental priorities:

- emergency response,

- use of transboundary water resources,

- monitoring and protection of flow and quality of transboundary water resources,

- evaluation/prevention of threat of hazardous material contamination,

- remediation of Caspian/Aral Seas, and

- development of environmental laws/regulations/infrastructure.

To catalyze activity in Central Asia, USCENTCOM has utilized the input from the REO and the STARS program, among others, to submit an environmental security item in their FY04-09 Program Objective Memorandum (POM). This program is called the Central Region Environmental Security program (CRESP). The initial request is for $\$ 18 \mathrm{M}$ over five years but there are 15 distinct budget review steps and changes can be expected. A portion of any environmental security funds will be for high-impact, short duration projects. The ideal initial program is one project for each of the five countries and several regional projects that are born multilateral. The Kaji-Say, Kyrgyzstan mine tailings project is viewed as a typical CRESP project. A list of selected country and regional projects is given in the Action Items section below.

It was observed that, even for the small set of projects identified by workshop participants, the expected available funds from all USG sources would be inadequate. There was considerable discussion regarding potential alternative donors and a separate document synthesizing that discussion and the preliminary strategy is being developed for later distribution. 


\section{Agenda \\ Central Asia Environmental Security Technical Workshop: Responding to the CENTCOM Vision}

Lawrence Livermore National Laboratory

(B132, Room 1781)

\section{Tuesday 6 August}

0730 Badging at LLNL West Gate Badge Office

0800 Greetings, Opening Remarks, and Meeting Objectives (Jeff Richardson) - B132, R1781

0805 Overview and Review (Jeff Richardson)

Origins, Role, and Status of Environmental Security in CENTCOM (Mike Bonadonna)

The Response of the Central Asia Regional Environmental Officer to Gen. DeLong's Request (Bob Watts)

Origins, Role, and Status of Environmental Security in LLNL (Jeff Richardson)

0830 Technical Development (LtCol. Mike Bonadonna)

The LLNL STARS Effort (Nina Rosenberg)

Priorities from the Region (Bob Watts)

Central Region Environmental Security Program - CRESP (Mike Bonadonna)

Identify Current Gaps and Develop Strategies to Close Them (All)

1030 Demonstration of the LLNL Counterproliferation Analysis and Planning System (CAPS)

- B132, R1102

$1200 \operatorname{LUNCH}(B 132, R 1781)$

1300 Financing (Richard Knapp)

The Weldon Process (Debbie Ball)

The 2004 CENTCOM POM (Mike Bonadonna)

DOE Funding of Environmental Security Projects in Central Asia (DOE)

Discussion (All)

1430 Demonstration of the Global Environmental Threat Consequence Analysis Tool GETCAT (Nina Rosenberg)

\section{BREAK}

1530 Strategies for the Donors' Conference (Bob Watts)

Review of Objectives for Donors' Conference (Mike Bonadonna)

Lessons from Previous Donors' Conferences (Fiona Hill)

Status of Donor's Conference and Its Structuring (All)

1700 Adjourn

- BBQ Dinner at the Ball Estate (Host's: Debbie and Charles Ball) 
LLNL-CENTCOM Central Asia Environmental Security Technical Workshop

\section{Wednesday 7 August}

0730 Meeting Room Available

0800 Review of Day 1 and Outstanding Action Items (LtCol. Mike Bonadonna)

0830 Develop Scope, Schedule, and Budget on Identified Projects (Andy Tompson)

1030 Demonstration of Groundwater Processes: Scaled-Physical and Computer Models B132, R1781 (Andy Tompson)

1115 The LLNL Noble Gas and Stable Isotope Laboratories - B151, R1131A\&B (Dave Smith)

- $\mathrm{LUNCH}$

1300 LLNL Facility Tour

1400 Tour of the LLNL National Atmospheric Release Advisory Center (NARAC) - B172

1530 Path Forward (Jeff Richardson)

1630 Depart for SF Giants-Chicago Cubs Baseball Game

CONTACT: Richard Knapp (925-423-3328)

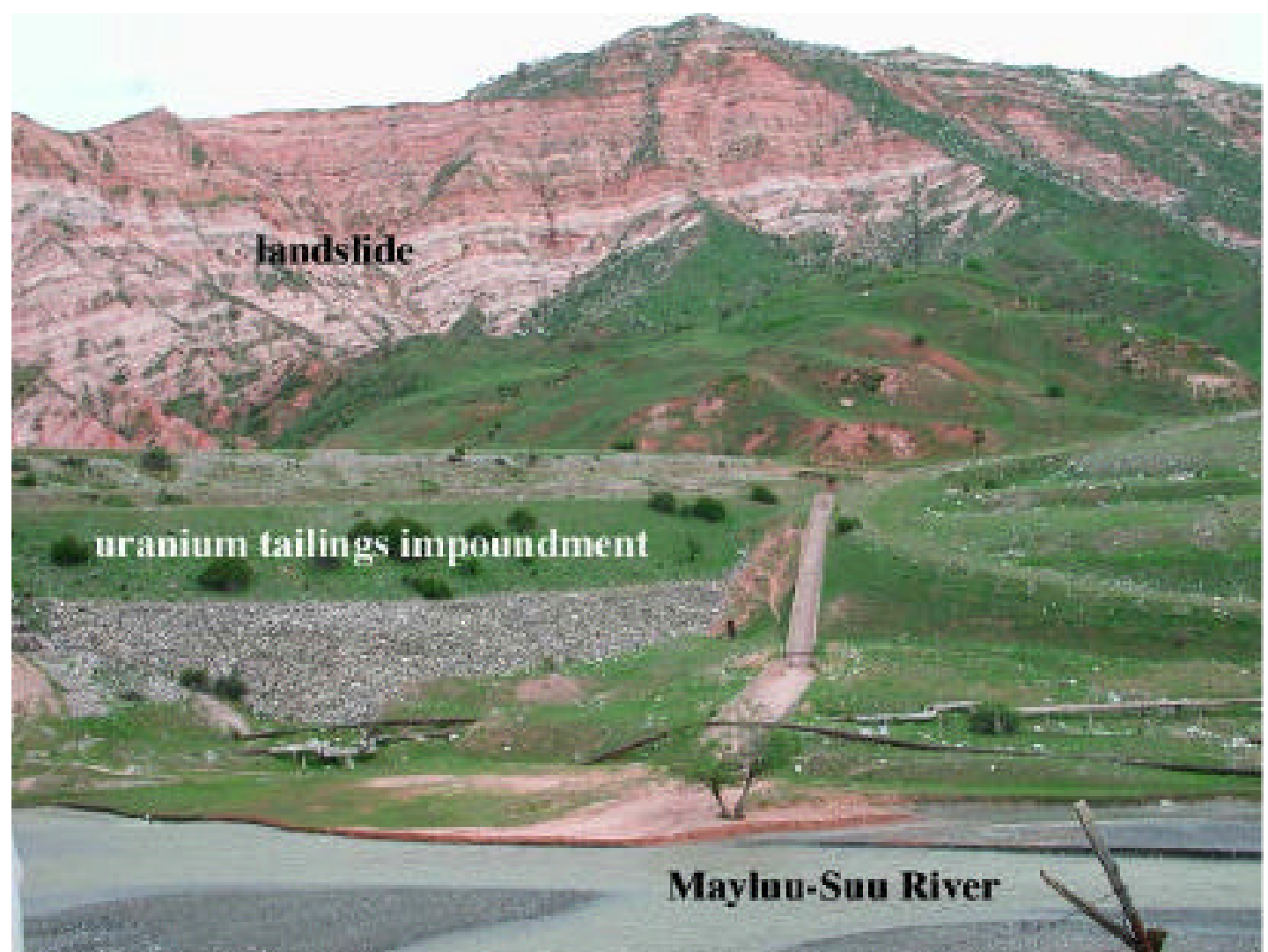

There are 23 uranium tailings impoundments and more than 200 landslides at Mayluu-Suu, Kyrgyzstan. Many of these impoundments are precariously poised on the banks of the Mayluu-Suu River, a tributary to the Syr-Darya, which courses through the Fergana Valley in Uzbekistan. This hand-held photograph shows a major landslide behind one uranium tailings impoundment and illustrates the potential for landslides to bulldoze radioactive tailings into the Mayluu-Suu River. 


\section{List of Participants}

\section{Debbie Ball}

Lawrence Livermore National Laboratory

ball10@1lnl.gov

\section{Dave Barber}

Sandia National Laboratory

dsbarbe@sandia.gov

Mike Bonadonna

U.S. Central Command

bonadomf@centcom.mil

\section{Mike Brown}

Oakland Operations Office

U.S. Department of Energy

mike.brown@oak.doe.gov

\section{Mike Congdon}

U.S. Department of Energy

michael.congdon@hq.doe.gov

\section{Gene DeLaTorre}

Consultant

genedela@erols.com

\section{Fiona Hill}

Brookings Institution

fhill@brookings.edu

\section{Richard Knapp}

Lawrence Livermore National Laboratory knapp4@1lnl.gov

\section{John Mentz}

Pacific Northwest National Laboratory

jake.mentz@pnl.gov

\section{Keith Nakanishi}

Lawrence Livermore National Laboratory nakanishi1@1lnl.gov

\author{
Ken Quitoriano \\ Oakland Operations Office \\ U.S. Department of Energy \\ ken.quitoriano@oak.doe.gov
}

\section{Richard Ragaini}

Lawrence Livermore National Laboratory

ragaini1@1lnl.gov

\section{Jeff Richardson}

Lawrence Livermore National Laboratory richardson6@1lnl.gov

Nina Rosenberg

Lawrence Livermore National Laboratory

rosenberg4@1lnl.gov

\section{David Smith}

Lawrence Livermore National Laboratory smith24@1lnl.gov

\section{Jerry Sweeney}

Lawrence Livermore National Laboratory sweeney3@1lnl.gov

\section{Andy Tompson}

Lawrence Livermore National Laboratory

tompson1@1lnl.gov

\section{Robert Watts}

U.S. Department of State

wattsrm@state.gov

bob@wattses.org

\section{Ned Wogman}

Pacific Northwest National Laboratory

ned.wogman@pnl.gov

\section{Jay Zucca}

Lawrence Livermore National Laboratory

zucca2@1lnl.gov 


\section{Action Items}

1. Distribute proceedings by 16 August

2. Develop proposals for high impact projects by 29 August to LLNL (knapp4@1lnl.gov) and LLNL to package to CENTCOM by 7 September

General Project Selection Criteria

In the U.S. interest

In the interest of the host country or region

Within financial and human resources limits

Country-Specific Project Selection Criteria

Environmental or disaster preparedness context

High impact

Tangible results

Two-year timeframe or less

Regional Project Selection Criteria

Include all of country-specific criteria

Born multilateral

Selected Projects

Kazakhstan: Ulba Metallurgical Plant (LLNL)

Kyrgyzstan: Mayluu-Suu uranium tailings impoundments (LLNL)

Tajikistan: Seismic Monitoring Network (LLNL)

Turkmenistan: Tabled for 21 August teleconference

Uzbekistan: Surface water monitoring (SNL)

Regional: GETCAT (LLNL)

Seismic (LLNL)

3. LLNL to summarize discussion and synthesize a plan for a funding conference by 14 August

4. Participants to actively ensure funded projects included in EUR/ACE Central Asia environmental projects list

5. Mike Congdon to acquire list of all funded projects on health, environment, and energy in Central Asia by 20 August

6. Mike Bonadonna to arrange for teleconference on 21 August

7. Participants to communicate results of workshop
a. Mike Bonadonna with OSD
b. Jake Mentz with Alan Hecht (NSC)
c. Fiona Hill with Matt Bryza (NSC) 
USCENTCOM Environmental Security Program

\section{USCENTCOM \\ ENVIRONMENTAL SECURITY \\ PROGRAM}

6 Aug 02

Lt Col Bonadonna, CCJ5-E

Purpose

To describe the origin and development of the USCENTCOM Environmental Security Program 


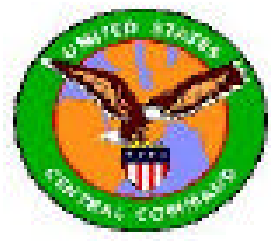

\section{Why is Environment a CENTCOM Mission?}

JSCP

Prioritized Regional Objects

Theater Security Cooperation Plan

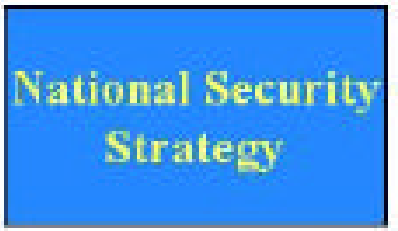

National Military Strategy

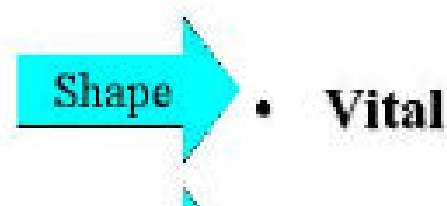

Respond - Important

Prepare

Other/Humanitarian

\section{Destabilizing Environmental Issues in CENTCOM's Region}

- Water Access, Quality, and Control

- Trans-boundary Resource Competition

- Migration, Refugees, and Land Use

- Public Health/HIV/Famine

- Industrial Pollution

- Environmental Degradation/Desertification

- Eco-Terrorism/War 


\section{Environmental Security \\ Vision}

USCENTCOM will address environmental issues that affect our collective national security in order to shape a positive regional security environment, prevent conflict and promote sustainable developments and stability. We will cooperate with other U.S. agencies, the DOS Environmental Hubs, NGOs, PVOs and international organizations to engage the militaries of the region, in support of civil authorities.

\section{Environmental Security \\ Program History}

- Began in the mid 1990's

- Development of ES Annex to the TEP

- 2000 Gulf States Environmental Security Conference

- CCJ5 takes the lead with CCJ2 and CCJ4 support

- Established Partnership with Lawrence Livermore National Lab

- 2001 CAS ESC: Mar 01 in Garmisch, GE

- 2002 CAS ESC: Apr 02 in Chiemsee, GE 


\section{Engagement Objectives Enhance Stability \& Avert Crisis}

\section{Resource \\ Management}
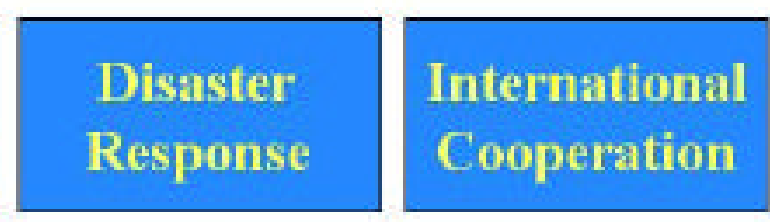

- Understand environmental issues impacting security

- Engage Regional Militaries

- Involve Civilian Leadership

- Encourage Planning and Execution

- Improve Civil-Military Cooperation

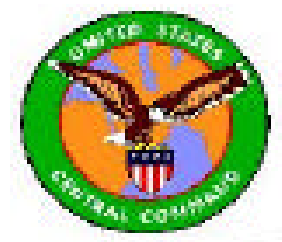

\section{CENTCOM Activities}

- Direct Role

- Warning and Analysis

- Assistance Programs

- Education and Training

- Military-to-Military Contacts

- Indirect Role

- Interagency Coordination and Support

- Bi-lateral and Multi-lateral Conferences

- Contingency Planning 


\section{Direct Role Examples}

- Analysis:

- Technical Assessments Supporting Operations

- Assistance:

- Water purification equipment

- Excess Defense Articles

- Engineering Projects

- Education and Training:

- Environmental Protection workshops

- Military-to-Military:

- Sharing waste treatment technologies to reduce water pollution

\section{Resources \& Funding}

- Funding for CAS Engagement

- Traditional CINC Activities (TCA)

- Warsaw Initiative Funds (WIF)

- Cooperative Threat Reduction (CTR)

- OSD Environmental Funding

- Defense Environmental Security International Cooperation (DESIC) Program

- Central Region Environmental Security Program

- Specific Initiative for Environmental Security Engagement and Improvement Projects 


\section{Environmental Security Program Status}

\section{Where Are We Now?}

- Developing USCENTCOM ES program for the Theater Security Cooperation Plan (CCJ5)

- Planning 2002 Gulf States ESC for Sep 02

- Coordinating LLNL projects

- Planning expanded ES-related Mil-Mil contacts

- Working with the USG Interagency for policy and program development

\section{The Need for Interagency Cooperation}

\section{Same Goals \\ Different Priorities - Different Resources}

Regional

Stability

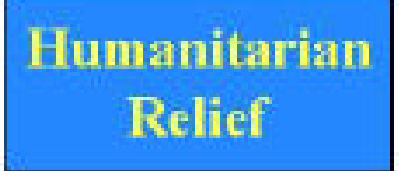

- Assistance Programs

- Education and Training

- Conferences \& Working Groups

- Negotiations 


\section{Way Ahead}

- Development of USG Policy Central Asian

- Including Environmental Security

- Ongoing since April 02

- GCC ES Conference

- 17, 18 Sep 02 in Qatar

- CAS ES Conference

- TBD

- CAS Donor's Conference

- TBD at State Department Discretion

\section{Environmental Security Program Summary}

Environmental Security is a key mission area for USCENTCOM

Engagement through Environmental Security improves regional stability and facilitates our access to the region

USCENTCOM will continue to support Environmental Security Cooperation with Central Asia and the Gulf States 


\section{The LLNL STARS Program}

\section{The STARS Effort}

Nina Rosenberg

LLNL

6 Aug 02

Central Asia Environmental Security Technical Workshop: Responding to the CENTCOM Vision

\section{History of STARS}

- LLNL has been active in environmental security for many years

- Middle East work began in 1997

- Border security work in Uzbekistan began in 1998

- Fact-finding trips, workshops in Kazakhstan, Kyrgyzstan 2000-2001

- STARS (Seience and Technology to Adwance Regional Security) acronym coined by LLNL Jan 02 for Weldon workshop on Central Asia

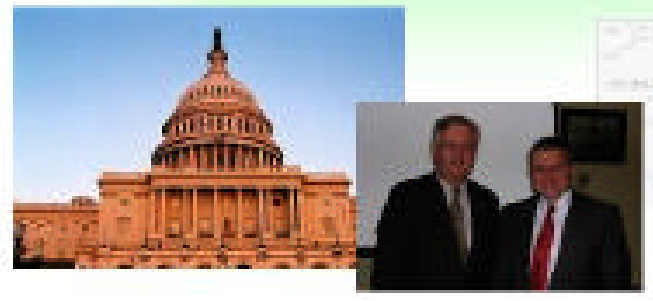

\footnotetext{
A Congressional Workihop on the Advancement of U.S. Netional Security Through Science and Technology Cooperation in Centrol Asia

14 Fbirawy 3003
} 


\section{What is STARS?}

- STARS is a program based on projects that are:

- collaborative

- bilateral/mulfilateral

- science and technology based

- STARS projects must

- provide an opportunity for engagement in the region of interest

- address real problems that could otherwise lead to destabilizing tensions in a region

- Other STARS objectives include:

- helping to rednee illieit smuggling of weapons and drugs

- promoting education and welfare of local population

\section{LLNL and STARS}

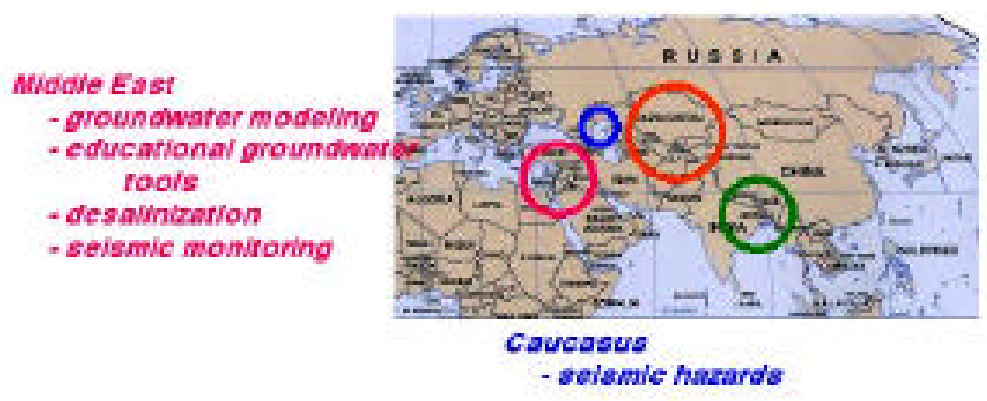

Sourh Asia

- seismic monitoning

Gentral Asie

- radionucido contaminatian

- water resources

- oll poilintion

- bovaler secunty

LLNL is engaged in STARS projects in several regions of the world important to U.S. national security 


\section{STARS/Central Asia and USCENTCOM}

\section{Environmental Security is USCENTCOM's primary option for assuring and} engaging the Central Asian states and promoting multilateral cooperation.

STARS/Central Asia directly supports (and can be a great vehicle for implementing and amplifying ) USCENTCOM's activities and objectives in envirommental security.

LLNL first-hand knowledge about the the enviroumental concerns in the region, science and techmology based measures to address these problems, and partmers for collaboration, as well as itslong history of involvement with national security matters, makes it a perfect partner for USCENTOM.

Topics for STARS/Central Asia projects

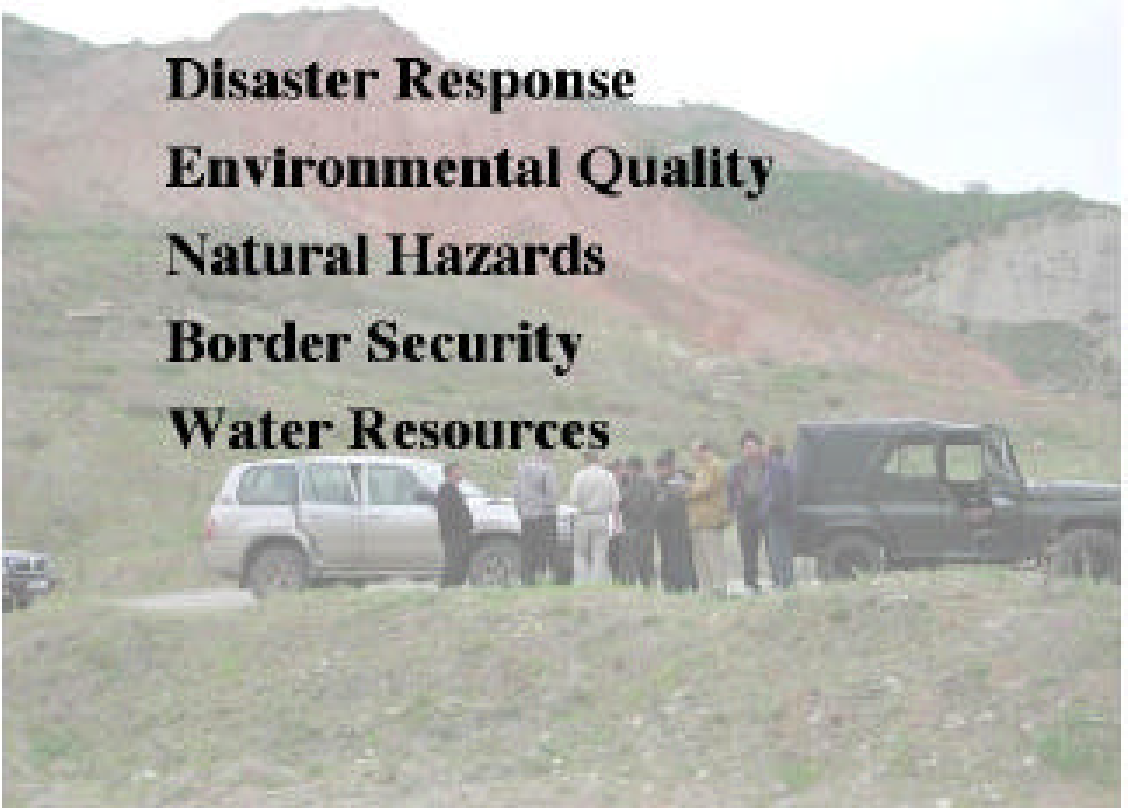




\section{One STARS project proposal concerns a former nuclear test site in Kazakhstan}

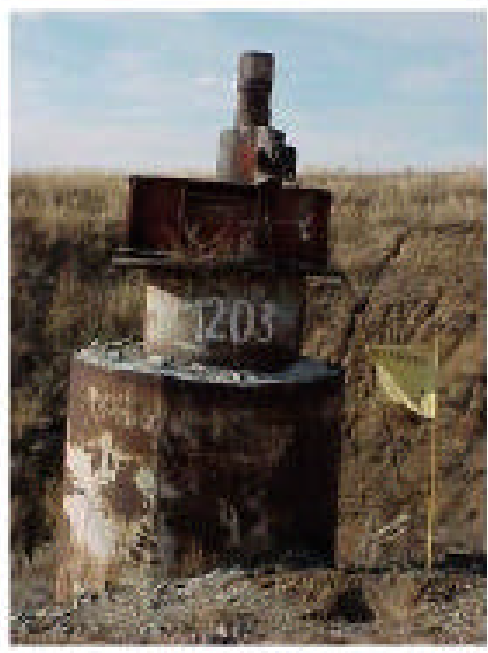

Photo of device emolacement shat associsted with undergrasond rucless is Bavapan ares at Sernipalarinsk
- The Soviet Union conducted over 400 nuclear tests at the Semipalatinsk Test Site in northern Kozakhstan

- Scientists from LLNL and Kazaktistan have developed a plan to assess the. threats of contamination of grounctwater and surface water from the underground tests

- Many aspects of this project are readily transferable to other contaminated sites in Central Asia

\section{Another focuses on waste disposal practices at an industrial facility in Kazakhstan}

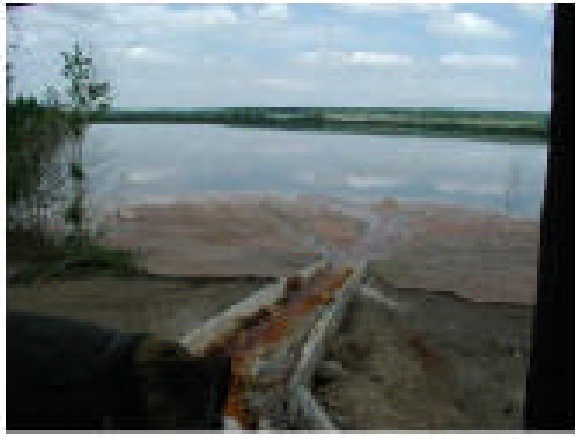

Typucsi dischisge of iliguid wastes ino starage pard at Aba
- The Ulba Metallur gical Plant is one of the oldest plants supporting the nuclesir cycle in the former Soviet Union

- The plant is a representative example of industrial pollution in Central Asia Leaking waste pouds at the stte containing toxic and radicective naterial threaten both the Irtysch River and nearby water supply wels

- LLNL and plant personnel have developed a plan to work together to character lze, manage and solve scane $\alpha$ the site's problems 


\section{Several project proposals address the problem of uranium mine tailings in Kyrgystan}

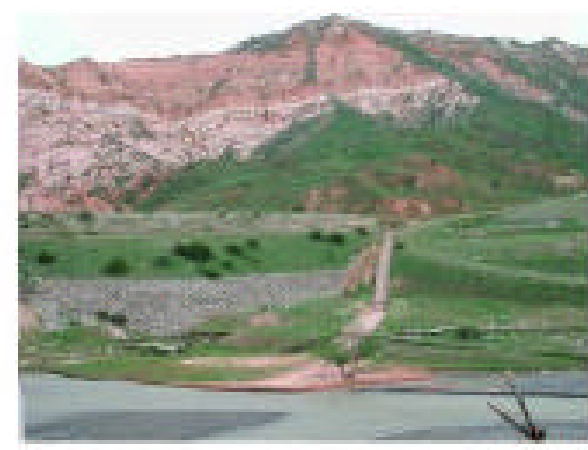

A mevor bandswide betwind a wancon taings imooundment at Maykuksur
- Uranium mine tailings pose a resal flureat to the water resuurces in the Fergana Valley and elsewhere in Central Asia

- In 2001, LLNL surveyed several sites in Kyr gyzstan with locel representatives from the mining industry

- Together with our Central Astan partners, we have developed a collaborative project to denonstrate mitigation strategies at such sites

Funds from Stute (AmbassadarTaylar's office) recently andhorised for Knj̈-Sny project

\section{STARS projects address border security in Uzbekistan}

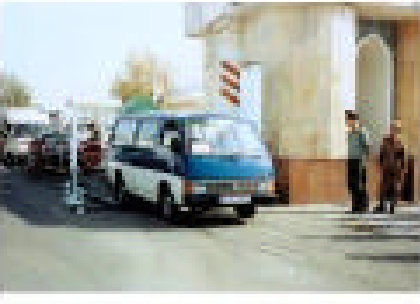

Equip border points of entry with capsbality to detect meapors of muss destruction and drugs

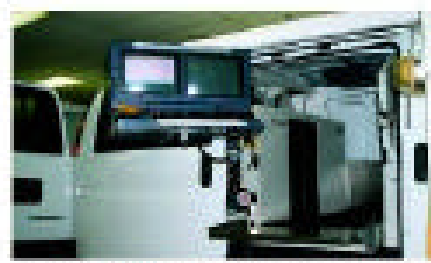

Uperade haboatory and mobile characterlzation expabilitios.
Expand on existing programs to develop commen science and teclmology tools and practices to promete regional border security

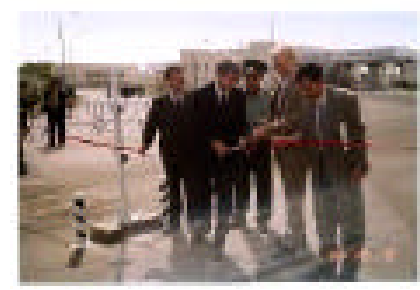

Promote regional inforanation exchange, standardk, and exercises

Suppow from Stane and DOD 


\section{Regional STARS/Central Asia project proposals}

Disaster response - Develop and exercise emergency response plans for individual states and region using GETCAT.

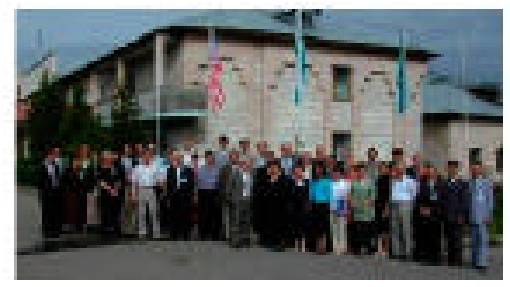

Caspian and Aral Seas - Idencify, locate, and classify point-sources of radionuclide and other hazardous contamination in the Caspian. Protect aquifers in Aral Sea from contamination.

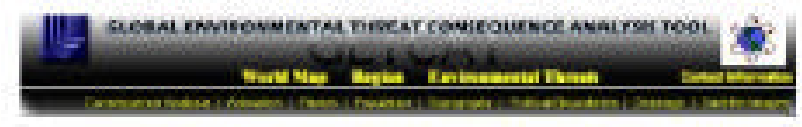

Water resources - Start with individual states and work toward regional network of water resources experts, with U.S. acting as honest broker and facilitator.

\section{STARS/Central Asia project proposals by State}

\section{- Kazakhstan}

- Assess radionuclide migration at Semipalatinsk

- Remediate groundwater at Ulba Metallungical Plant

UKAA Marage water resources in the Lake Balkash-If River Basin

\section{- Kyrgyzstan}

- Eliminate threat of Kaji-Say U contamination to Lake- Issyk-Kol

- Eliminate threat of Mayluu-Suu U tailings to Fergana Valley

- Assess risk of Ak-Tuz site and rebabilitate U talings impoundments

- Prevent failure of and human exposure to threat of Ming-Kush tailings

- Decommission Kara-Balta U tailings to prevent contamination of ecreal erops

- Greation of base for application of modern ingigation technologies in . Issyk-Kol region

- Tajikistan

- Restore seismic monitoring capability

\section{- Uzbekistan}

- Expand on existing programs to develop common science and techoology tools and practices to promote regional border security

\section{- Turkmenistan}

$-? 9$

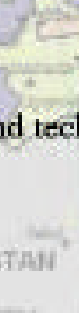

Fakightarl

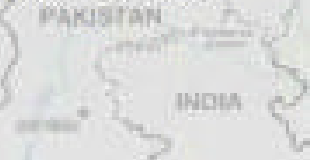




\section{The environmental component of regional security is emerging as a key element of \\ USG policy in Central Asia.}


The Central Region Environmental Security Program
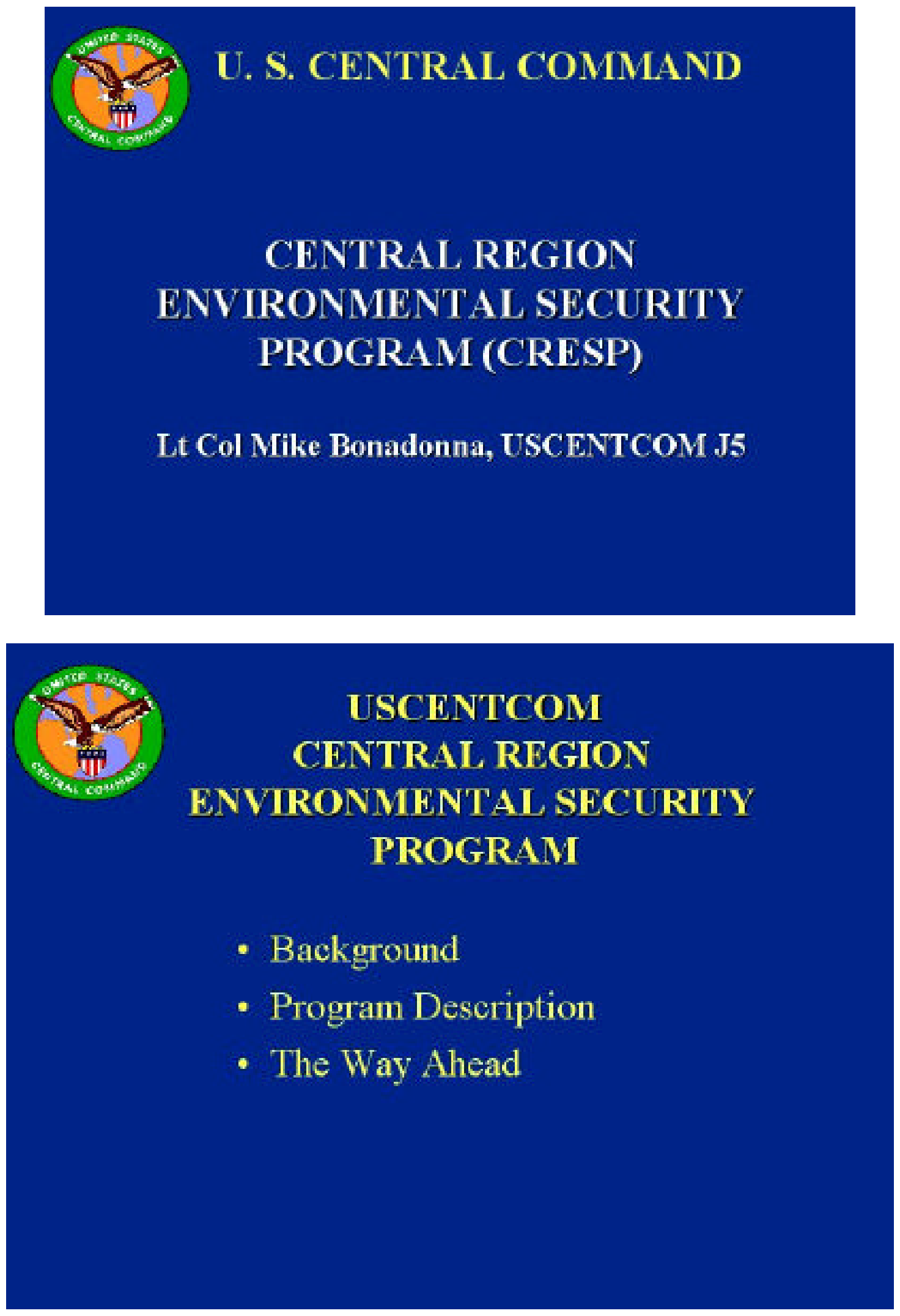


\section{BACKGROUND}

- USCENTCOM wishes to take a more proactive role in Environmental Security

- Result of the 2002 Central Asian Environmental Security Conference

- CRESP will address longstanding regional environmental problems

- CRESP is intended to serve as a catalyst for environmental mitigation and consequence management projects of other agencies

\section{PROGRAM DESCRIPTION}

- Program runs from FY04 to FY09 (if funded)

- Covers activities throughout the CENTCOM AOR

- Total program value is roughly $\$ 18 \mathrm{M}$

- Program funds

-2 Contractor positions at HQ USCENTCOM and Regional Environmental Hubs

- 2 Environumental Security Conferences per year

- \$1M-\$2M per year for environmental engineering projects

- Up to 20 exchanges of environmental experts per year 


\section{THE WAY AHEAD}

- USCENTCOM will work with Joint Staff to secure funding for CRESP through normal channels

- CCJ5-E dedicating one officer to manage Environmental Security and prepare for CRESP execution

- Program development to occur in FY03

- Identifying contractor support

- Planning exchange program

- Determining Environmental Engineering projects 